\title{
PENGARUH RETURN ON ASSET DAN NET PROFIT MARGIN TERHADAP HARGA SAHAM
}

\section{THE EFFECT OF RETURN ON ASSETS AND NET PROFIT MARGIN ON SHARE PRICES}

\author{
Abdul Hamid ${ }^{1}$, Dailibas ${ }^{2}$ \\ Universitas Singaperbangsa Karawang,Indonesia ${ }^{1,2}$ \\ abdulhamid23345@gmail.com ${ }^{1}$
}

\begin{abstract}
In the last few years, the national automotive industry has shown fairly attractive developments that are in great demand. This study aims to examine the effect of ROA and NPM on stock prices in automotive and component manufacturing companies listed on the IDX for the 2014-2019 period. The sample in this study there were 5 companies from 13 companies as a population, sampling using purposive sampling, so that the number of samples studied was 30 data for 6 years. The research method used is descriptive quantitative research methods. Based on the results of the research conducted, the authors concluded with the t test and f test, namely: ROA has a negative effect on stock prices, NPM has a positive effect on stock prices. Simultaneously ROA and NPM have an effect on stock prices. Based on this research, it is known that the stock price can be described as $53.3 \%$ by ROA and NPM and there are still $46.7 \%$ other factors outside the independent variables in this study that can describe the stock price.
\end{abstract}

Keywords: ROA, NPM, Stock Price.

\begin{abstract}
ABSTRAK
Dalam beberapa tahun terakhir, industri otomotif nasional menunjukkan perkembangan yang terbilang atraktif sedang banyak diminati. Penelitian ini bertujuan untuk menguji pengaruh ROA dan NPM terhadap Harga Saham pada perusahaan manufaktur subsektor otomotif dan komponen yang terdaftar pada BEI periode 2014-2019. Sampel pada penelitian ini ada 5 perusahaan dari 13 perusahaan sebagai populasi, penarikan sampel mengunakan Purposive sampling, Sehingga jumlah sampel yang di teliti adalah 30 data selama 6 tahun. Metode penelitian yang digunakan adalah metode penelitian deskriptif kuantitatif. Berdasarkan hasil penelitian yang dilakuakan penulis didapat kesimpulan dengan uji $t$ dan uji f,yaitu : ROA berpengaruh negatif terhadap Harga Saham, NPM berpengaruh positif terhadap Harga Saham. Secara simultan ROA dan NPM berpengaruh terhadap Harga Saham. Berdasarkan penelitian ini diketahui bahwa Harga saham dapat di gambarkan sebesar sebesar 53,3\% oleh ROA dan NPM dan masih ada $46,7 \%$ faktor-faktor lain diluar variabel independent dalam penelitian ini yang dapat menggambarkan Harga Saham.
\end{abstract}

Kata Kunci: ROA, NPM, Harga Saham. 


\section{PENDAHULUAN}

Di era globalisasi saat ini, pasar modal telah mengalami perkembangan yang pesat dan memegang peran penting dalam memobilisasi dana dari masyarakat yang ingin berinvestasi di pasar modal. Dalam artian lain investasi adalah suatu bentuk aktiva dengan suatu harapan mendapatkan keuntungan pada masa mendatang. Dengan demikan, pasar modal juga bisa diartikan sebagai pasar untuk memperjualbelikan sekuritas yang umumnya memiliki umur lebih dari satu tahun, seperti saham dan obligasi.

Dalam hal ini, peneliti memilih perusahaan Sub Sektor Otomotif sebagai landasan penelitian yang sedang berlangsung. Dalam beberapa tahun terakhir, industri otomotif nasional menunjukkan perkembangan yang terbilang atraktif sedang banyak diminati. Ini merupakan bagian dari imbas positif pertumbuhan jumlah kelas menengah Indonesia selama satu dasawarsa terakhir atau 10 tahun terakhir ini.

Saham merupakan salah satu instrumen pasar modal yang paling diminati investor karena memberikan tingkat keuntungan yang menarik. Saham dapat didefinisikan sebagai tanda penyertaan modal seorang atau sepihak (badan usaha) dalam suatu perusahaan atau perseroan terbatas. Dengan menyertakan modal tersebut, maka pihak tersebut memiliki klaim atas pendapatan perusahaan, klaim atas asset perusahaan, dan berhak hadir dalam rapat umum pemegang saham (RUPS).

Berdasarkan data harga saham perushaan otomotif bahawasannya terjadi keanehan dan mengalami persaingan yang sangat ketat pada setiap emitennya. Dimana beberapa emiten mengalami kenaikan fluktuatif dan trennya meningkat. Akan tetapi dari data harga saham pada setiap emiten tersebut berbeda-beda dan lebih unggul pada perusahaan ASII tahun 2017 yaitu Rp. 8.300 dan BRAM pada tahun 2019 sebesar Rp. 10.800. Sedangkan harga saham terendahnya pada perusahaan INDS tahun 2015 sebesar Rp. 350 dan SMSM tahun 2016 sebesar Rp. 980. Dalam hal ini penjualan produk yang lebih tinggi dan menyebabkan investor lebih tertarik pada perusahaanperusahaan tersebut.

Tinggi rendahnya harga saham ini ditentukan oleh orang-orang yang melakukan jual beli saham di pasar modal yg biasa disebut investor. Semakin populer saham suatu perusahaan, harganya akan semakin mahal, begitu juga sebaliknya. Idealnya setiap orang memutuskan membeli suatu saham perusahaan berdasarkan analisis fundamental yang menunjukkan nilai asli perusahaan. Dengan adanya harga saham, dapat mudahkan dalam menentukan harga dari suatu saham pada pasar yang sedang berlangsung. Namun ketertarikan investor dalam membeli saham dapat di liat dari beberpa factor-faktor yang dapat mempengaruhi harga saham tersebut , yaitu pada rasio keuangan perusahaan, namun penulis akan fokus pada bagian profitabilitas (ROA dan NPM)

Rasio umum yang digunakan sebagai alat ukur kinerja keuangan perusahaan adalah Return on Assets (ROA). Menurut Munawir (2010) menyatakan bahwa Return On Asset adalah salah satu bentuk dari ratio profitabilitas yang dimaksudkan untuk dapat mengukur kemampuan perusahaan dengan keseluruhan dana yang digunakan untuk operasinya perusahaan untuk menghasilkan laba. Menurut Hery (2015) menyatakan bahwa Net Profit Margin merupakan rasio yang digunakan untuk mengukur besarnya persentasi laba bersih atas 
penjualan bersih.

Berdasarkan data mengenai Return On Asset pada perusahaan manufaktur sub sektor otomotif pada tahun 2014-2019 mengalami fluktuasi, pada tahun 2014 kenaikan terbesar nilai ROA terdapat pada perusahaan Selamat Sempurna Tbk (SMSM) sebesar $24.09 \%$, sedangkan penurunan terbesar nilai ROA pada tahun 2015 dialami oleh perusahaan Indospring Tbk (INDS) sebesar $\quad 0.10 \%$. Dengan demikian nilai ROA mengalami fluktuasi dari tahun 2014-2019.

Berdasarkan data mengenai Net Profit Margin pada perusahaan manufaktur sub sektor otomotif pada tahun 2014-2019 mengalami fluktuasi, pada tahun 2016 kenaikan terbesar nilai NPM terdapat pada perusahaan Selamat Sempurna Tbk (SMSM) sebesar $17.44 \%$, sedangkan penurunan terbesar nilai NPM pada tahun 2015 dialami oleh perusahaan Indospring Tbk (INDS) sebesar $\quad 0.12 \%$. Dengan demikian nilai NPM mengalami fluktuasi dari tahun 2014-2019.

\section{METODE PENELITIAN}

Adapun metode penelitian yang penulis gunakan pada penelitian ini adalah metode penelitian deskriptif kuantitaif .Variabel penelitian yang penulis angkat adalah Variabel bebas (independent variable) atau Variabel independen yaitu ROA (X1) dan NPM (X2)

Harga Saham adalah Variabel terikat (dependet variable) yaitu Variabel yang dipengaruhi atau yang terjadi akibat karena adanya variabel independen, maka dalam penelitian ini yang menjadi variabel dependen. Daya yang digunakan penelitian berasal dari pihak ke tiga yaitu Bursa Efek Indonesia (BEI) dalam bentuk laporan keuangan maka dari itu ini meununjukan mengunakan data sekunder.

Sampel pada penelitian ini ada 5 perusahaan dari 13 perusahaan sebagai populasi, penarikan sampel mengunakan Purposive sampling, Sehingga jumlah sampel yang di teliti adalah 30 data selama 6 tahun.

\section{Teknik Analisis Data}

Teknik analisis data yang dilakukan oleh peneliti mengunakan Teknik analisis statistic Deskriptif yang bertujuan untuk mengambarkan variabel tanpa menarik kesimpulan dan analisis verifikatif dimana analisis ini digunakan untuk mengetahu hubungan antara variabel independent terhadap variabel dependen,analisis yang digunakan penelitian dengan Regresi Linear Berganda, dan peneliti ingin mengetahui seberapa besar varibel dependen dipengaruhi variabel independent dengan Koefien Determinasi, Uji $\mathrm{t}$ (Parsial), Uji F(Simultan).

\section{HASIL DAN PEMBAHASAN Analisis Statistik Deskriptif}

Tabel 1 Hasil Analisis Statistik Deskriptif

\begin{tabular}{lrrrrr}
\hline & N & Min & Max & Mean & $\begin{array}{c}\text { Std. } \\
\text { Deviation }\end{array}$ \\
\hline ROA & 30 &, 08 & 24,09 & 8,668 & 7,16127 \\
\hline NPM & 30 &, 12 & 17,44 & 8,799 & 4,84793 \\
\hline HS & 30 & 350 & 10800 & 3876,67 & 2972,73 \\
\hline Valid & 30 \\
N & & & \\
\hline \multicolumn{5}{l}{ Sumber: Data Olahan (2020) }
\end{tabular}

Berdasarkan analisis statistic deskriptif yang dilakukan penelitian dikemukanakan bahwa data yang di teliti sebanyak 30 dan menunjukan ROA memiliki nilai minimum sebesar 0,08 dan nilai max sebesar 24 namun NPM memeiliki nilai minimum 0,12 sedangkan nilai max sebesar 17,44 dan harga saham sebesar 350 nilai 
minimumnya dan nilai max sebesar 3876,67 .

Pada penelitian ini dapat diketahui juga data yang baik atau tidaknya dari variasi datanya dan diketahui nilai ROA, NPM dan Harga Saham memeiliki nilai mean yang lebih besar dari standar deviasai yang artinya dalam penelitian ini data tidak terlalu bervariasi dan menunjukan data yang baik.

\section{Koefisien Determinas $\left(\mathbf{R}^{2}\right)$}

\begin{tabular}{ccc}
\multicolumn{3}{c}{ Tabel 2 Uji Koefisien Determinasi (R2) } \\
\hline Model & R & R Square \\
\hline 1 &, $730^{\mathrm{a}}$ &, 533 \\
\hline
\end{tabular}

Sumber : Data Olahan (2020)

Berdasarkan hasil perhitungan nilai koefisen determinasi (Adjust $\mathrm{R}$ Square) diketahui pengaruh dari ketiga variabel independen (ROA dan NPM) terhadap Harga Saham sebesar 0,533 atau 53,3\%. Artinya 53,3\% variabel ROA dan NPM menjelaskan Harga saham. sedangkan sisanya sebesar $44,3 \%$ dijelaskan oleh faktor-faktor lain diluar variabel independen dalam penelitian ini atau tidak masuk dalam model regresi.

\section{Analisis Regresi Linier Berganda}

Tabel 3 Hasil Uji Analisis Regresi Linier Berganda

\begin{tabular}{llcr}
\hline \multirow{2}{*}{ Model } & \multicolumn{2}{c}{$\begin{array}{c}\text { Unstandardized } \\
\text { Coefficients }\end{array}$} \\
\cline { 2 - 3 } & \multicolumn{1}{c}{$\mathrm{B}$} & \multicolumn{2}{c}{ Std. Error } \\
\hline \multirow{2}{*}{1} & (Constant) & 432,936 & 946,081 \\
\cline { 2 - 3 } & ROA & $-794,514$ & 145,861 \\
\cline { 2 - 3 } NPM & 1174,123 & 215,463 \\
\hline
\end{tabular}

Sumber : Data Olahan (2020)

Pada umumnya sebelum melakukan oengujian regresilinier berganda akan dilakukan dulu pengujian asumsi klasik untuk menunjukan apakah data berdistribusi normal dan memnuhi syarta dengan tidak memeiliki gejalah autokorelasi, multikolinieritas dan heteroskedestisitas. Dan di dapati bahwa data berdistribusi normal dan memenuhi syarat untuk dilakukannya analisis regresi linier berganda

Berdasarkan persamaan regresi linear berganda diatas, dapat dijelaskan sebagai berikut: nilai konstanta pada analisisi regresi linier brganda 432,936 yang artinya jika variabel ROA dan NPM tidak mempengaruhi Harga Saham atau nilai nya sama dengan 0 (nol), maka rata-rata Harga Saham sebesar 432,935. Pada nilai koefisien regresi variabel ROA (X1) adalah Negatif, sedangkan pada nilai NPM menunjukan arah postif, arah negative dan postif pada regresi linier bergana ini bertujuan untuk memprediksi kemana arah variabel independent mempengaruhi variabel dependen.

Nilai koefisien regresi ROA mempengaruhi negative sebesar 794,514 harga saham, Nilai koefisien regresi NPM mempengaruhi positif Harga saham sebesar 1174,123.

\section{Uji Parameter Individual atau Parsial} (Uji t)

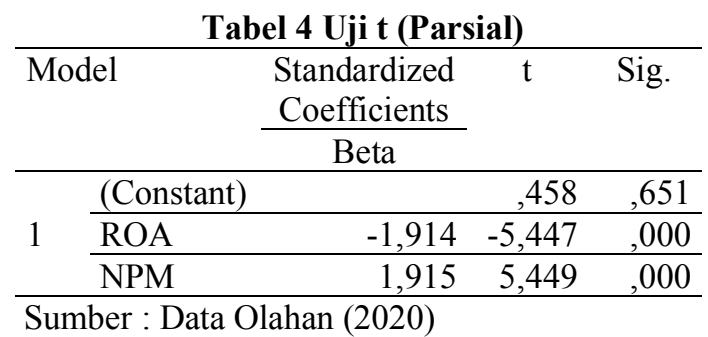

Uji signifikansi parsial (uji t) untuk masing-masing dari variabel independen (bebas) yaitu ROA, dan NPM terhadap variabel dependen (terikat) yaitu Harga Saham dari $\mathrm{T}$ hitung yang didapat $\mathrm{n}: 30, \mathrm{k}: 2$, yaitu 2,051, yang disajikan sebagai berikut: 
1. Hasil pengujian parsial uji-t antara variabel ROA dengan Harga Saham menunjukkan Nilai t hitung sebesar sebesar negative 5,447 dan diperoleh angka $\mathrm{t}$ tabel sebesar 2,051 sehingga t hitung $>\mathrm{t}$ tabel, maka secara parsial ROA mempengaruhi secara negatif pada Harga Saham.

2. Uji secara parsial antara variabel NPM dengan Harga Saham menunjukkan Nilai $t$ hitung sebesar sebesar 5,449 dan diperoleh angka t tabel sebesar 2,051 sehingga $t$ hitung $>\mathrm{t}$ tabel, maka secara parsial NPM mempengaruhi secara positif pada Harga Saham

\section{Uji Simultan (Uji F)}

Tabel 5. Uji F

\begin{tabular}{lllr}
\hline Model & & F & Sig. \\
\hline \multirow{3}{*}{1} & Regression & 15,401 &, $000^{\mathrm{b}}$ \\
\cline { 2 - 4 } & Residual & & \\
\cline { 2 - 3 } & Total & & \\
\hline
\end{tabular}

Sumber : Data Olahan (2020)

Nilai $\mathrm{F}$ hitung pada penelitian ini sebesar 15,401 dan $\mathrm{f}$ tabel $\mathrm{N}: 30 \mathrm{k}: 2$, sebesar 3,34 yang artinya nilai Fhitung $>$ Ftabel yang menunjukkan bahwa Ho ditolak dan Ha diterima. Dengan nilai tersebut dapat disimpulkan bahwa ROA (X1), dan NPM (X2). Secara simultan berpengaruh terhadap Harga Saham (Y) pada perushaan Subsektor Otomotif dan komponen yang terdaftar pada BEI periode 2014-2019.

\section{Pengaruh ROA terhadap Harga Saham}

Hasil pengujian parsial uji-t antara variabel ROA dengan Harga Saham menunjukkan Nilai $\mathrm{t}$ hitung sebesar sebesar negative 5,447 dan diperoleh angka $t$ tabel sebesar 2,051 sehingga $t$ hitung $>t$ tabel, maka secara parsial ROA mempengaruhi secara negatif pada Harga Saham

Rasio umum yang digunakan sebagai alat ukur kinerja keuangan perusahaan adalah Return on Assets (ROA) dan ROA memiliki pengaruh yang besar untuk harga saham walaupun pada penelitian ini menunjuka nilai yang negarif. Menurut Munawir (2010) menyatakan bahwa Return On Asset adalah salah satu bentuk dari ratio profitabilitas yang dimaksudkan untuk dapat mengukur kemampuan perusahaan dengan keseluruhan dana yang digunakan untuk operasinya perusahaan untuk menghasilkan laba. Pengaruh yang negative ini bisa diakibatkan oleh karena beberpaa peruhahaan masih banyak yang mengunakan nilai dolar sebagai nilai tukar atau pada laporan keuangan sehingga dapat mempengaruhi investor Investor tidak melihat Return On Asset sebagai indikator investasi. Seperti penelitian yang terdahulu Secara parsial variabel Return On Asset (ROA) yang berpengaruh negative terhadap harga saham (Mahfud, 2014; Feri, 2013). Sedangkan menurut Penelitian yang dilakukan oleh Kundiman \& Hakim (2016), Murniati (2016), Manoppo (2015) menyatakan bahwa ROA berpengaruh positif terhadap Harga saham. Menurut Rorong et al. (2017), dimana ROA berpengaruh tidak signifikan terhadap harga saham

\section{Pengaruh NPM terhadap Harga Saham}

Uji secara parsial antara variabel NPM dengan Harga Saham menunjukkan Nilai $t$ hitung sebesar sebesar 5,449 dan diperoleh angka $t$ tabel sebesar 2,051 sehingga $t$ hitung $>t$ tabel, maka secara parsial NPM mempengaruhi secara positif pada Harga Saham. Rasio yang digunakan untuk mengukur besarnya persentasi 
laba bersih atas penjualan bersih adalah Rasio Net Profit Margin (NPM) (Hery, 2015)

Penelitian ini di dukung oleh Watung \& Ilat, (2016) dengan hasil Secara parsial Net profit Margin berpengaruh signifikan terhadap harga saham Pada Perusahaan Perbankan Di Bursa Efek Indonesia Periode 20112015. Namun ada penelitian yang bertentangan yang menyatakan bahwa NPM berpengaruh negatif (Solihin, 2017; Egam et al., 2017)

\section{Pengaruh ROA dan NPM terhadap Harga Saham}

Nilai F hitung pada penelitian ini sebesar 15,401yang artinya nilai Fhitung $>$ Ftabel yang menunjukkan bahwa Ho ditolak dan $\mathrm{Ha}$ diterima. Dengan nilai tersebut dapat disimpulkan bahwa ROA (X1), NPM (X2). Secara simultan berpengaruh terhadap Harga Saham (Y) pada Subsektor Otomotif yang terdaftar pada BEI periode 20142019.

\section{PENUTUP \\ Kesimpulan}

Berdasarkan penelitian yang telah dilakukan mengenai Pengaruh ROA dan NPM terhadap Harga Saham pada Sub Sektor Otomotif yang terdaftar di BEI periode 2014-2019 maka dapat diambil kesimpulan sebagai berikut :

1. ROA berpengaruh Negatif dan Signifikan Terhadap Harga Saham pada perusahaan sub sektor otomotif periode 2014-2019.

2. NPM berpengaruh Positif dan Signifikan terhadap Harga Saham pada perusahaan sub sektor otomotif periode 2014-2019.

3. Pengaruh ROA dan NPM Terhadap Harga Saham pada perusahaan sub sektor otomotif periode 2014-2019.

\section{Saran}

Bagi perusahaan disarankan untuk lebih memperhatikan dan meningkatkan kinerja perusahaan khususnya pada profitabilitas rasio Return On asset (ROA). Karena pada nilai ROA pada perusahaan Otomotif masih belum optimal. Dimana dari penjelasan dalam penelitian ini nilai ROA selalu mengalami fluktuatif pada setiap tahunnya. Maka itu untuk meningkatkan ROA dapat dilakukan dengan meningkatkan laba bersih setelah pajak dan mengurangi total aktiva yang diinvestasikan perusahaan dan terutama menekan biaya yang dapat mengurangi laba terlalu tinggi. Karena dengan melihat nilai ROA dapat menjadi nilai tersendiri bagi investor bagaimana kemampuan perusahan dalam menghasilkan laba.

Penelitian ini memiliki keterbatasan hanya meneliti variabel ROA dan NPM saja sebagai variabel yang mempengaruhi Harga Saham, dan pada lokasi penelitian hanya sub sector otomotif dengan sampel 5 perusahaan. Untuk peneliti selanjutnya, diharapkan dapat menggunakan factor-faktor internal lainnya yang mempengaruhi Harga Saham selain variabel yang digunakan oleh peneliti, dan memperluas lokasi mapun perusahaan, Dan diharapkan peneliti selanjutnya bisa menambah periode waktu penelitian atau lebih di perincih seperti per semester, triwulan maupun perbulan, dan factor factor lain baik internal maupun eksternal agar hasil yang diperoleh mempunyai cakupan yang lebih luas dan hasil yang akurat serta memperluas objek penelitian, sehingga tidak hanya terbatas pada satu subsector perusahaan saja. 


\section{DAFTAR PUSTAKA}

Egam, G. E., Ilat, V., \& Pangerapan, S. (2017). Pengaruh Return On Asset (ROA), Return On Equity (ROE), (NPM), Dan (EPS) Terhadap Harga Saham Perusahaan Yang Tergabung Dalam Indeks LQ45 Di Bei Periode Tahun 2013-2015. Jurnal EMBA, 5(1)

Feri (2013). Pengaruh Rasio Profitabilitas Terhadap Perubahan Harga Saham Pada Perusahaan Sektor Properti yang Listing di Bursa Efek Indonesia periode 2008-2012. Jurnal Surabaya, Fakultas Ekonomi UNS.

Hery. (2015). Analisis Laporan Keuangan. Yogyakarta: Center For Academic Publishing Services.

Kundiman, A., \& Hakim, L. (2016). Pengaruh Current Ratio, Debt To Equity Ratio, Return On Asset, Return On Equity Terhadap Harga Saham Pada Indeks LQ 45 Di BEI Periode 2010-2014. Among Makarti, 9(18), 80-98.

Mahfud, E. F (2014). Pengaruh faktorfaktor fundamental terhadap harga saham syariah sektor cosumer goods di BEI 20112013. UIN Syarif

Murniati, S. (2016). Effect Of Capital Structure, Company Size And Profitability on the Stock Price of Food And Beverage Companies Listed on the Indonesia Stock Exchange. Information Management And Business Review, 8(1), 23- 29.
Manoppo, C. P. (2015). The Influence of ROA, ROE, ROS, And EPS On Stock Price. Jurnal EMBA, 3(4), 691-697.

Munawir, S. (2010). Analisis laporan Keuangan Edisi keempat. Yogyakarta: Liberty.

Rorong, A., Saerang, I. S., \& Untu, V. (2017). Analisis Risiko Sistematis dan Faktor Fundamental Terhadap Harga Saham Pada Perusahaan Sektor Properi Yang Terdaftar di Bursa Efek indonesia. Jurnal EMBA, 5(3), 4015-4025.

Solihin, Siti. (2017). Analisis Pengaruh Net Profit Margin (NPM), Return On Asset (ROA), Return On Equity (ROE) Dan Earning Per Share (EPS) Terhadap Harga Saham Pada Perusahaan Manufaktur Yang Terdaftar Di BEI Tahun 2013-2015. Universitas Muhammadiyah Surakarta,

Watung, R. W., \& Ilat, V. (2016). Pengaruh Return On Asset (ROA), Net Profit Margin (NPM), Dan Earning Per Share (EPS) Terhadap Harga Saham Pada Perusahaan Perbankan Di Bursa Efek Indonesia Periode 2011-2015. Jurnal EMBA, 4(1) 